\title{
Relative importance of organic- and iron-based colloids in six Nova Scotian lakes
}

\author{
Lindsay E. Anderson ${ }^{1,2}$, Benjamin F. Trueman $\mathbb{D}^{1,2 凶}$, Dewey W. Dunnington ${ }^{1,2}$ and Graham A. Gagnon ${ }^{1}$
}

Dissolved organic matter (DOM) concentrations have been increasing in parts of the northern hemisphere for several decades. This process-brownification-often accompanies increasing iron and aluminum, but the metal-DOM interactions these concurrent trends imply are poorly described. Here we used field-flow fractionation with UV and ICP-MS detection to measure the size distribution of colloidal iron, aluminum, manganese, copper, uranium, and chromophoric DOM in six lakes over six months. Five of these lakes have browned to some degree in the past three decades, with linear increases in organic carbon and color ranging from

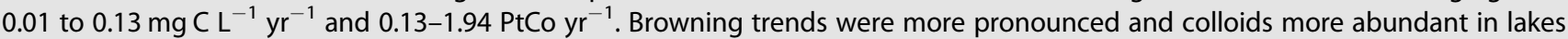
with wetlands in their catchments. Iron and aluminum were present in two primary fractions, sized nominally at 1 and $1000 \mathrm{kDa}$. The $1 \mathrm{kDa}$ fraction included the primary DOM signal, while the $1000 \mathrm{kDa}$ fraction absorbed minimally at $254 \mathrm{~nm}$ and likely represents iron-rich (oxyhydr)oxides. Colloidal manganese was sized at $1000+\mathrm{kDa}$, whereas colloidal copper and uranium occurred primarily at $1 \mathrm{kDa}$. These associations fit with a pattern of increasing DOC, iron, aluminum, and color in the region's lakes. They represent a significant challenge for drinking water treatment systems, especially those in remote communities. Given that browning trends are expected to continue, monitoring plans would better inform treatment process design and operation by characterizing DOM and iron-rich, primarily inorganic colloids that contribute to adverse water quality outcomes.

npj Clean Water (2021)4:26; https://doi.org/10.1038/s41545-021-00115-4

\section{INTRODUCTION}

Dissolved organic carbon (DOC) concentrations have been increasing in many lakes across Scandinavia, the UK, and northeastern North America for several decades. Some European lakes have seen increases of up to $0.15 \mathrm{mg} \mathrm{CL}^{-1} \mathrm{yr}^{-1}$. A concurrent increase in water color-brownification-is common ${ }^{1,2}$ and both are attributed to climate change $e^{3-5}$, declining atmospheric acid deposition, and land use change $\mathrm{e}^{2,5-7}$. Browning lakes often exhibit increasing iron $^{8-10}$ and aluminum concentrations ${ }^{11,12}$.

Brownification has important implications for the provision of safe drinking water. Increasing water color usually implies greater concentrations of humic and fulvic acids ${ }^{13-15}$, which bind metals and stabilize iron, aluminum, and other metal (oxyhydr)oxides ${ }^{16-19}$. Dissolved organic matter (DOM) and metal oxide colloids contribute to the mobility of lead and other toxic metals, representing a potential risk to human health if they are not removed during treatment. Moreover, the aromatic carbon associated with water color is particularly reactive with chlorine, yielding large quantities of toxic disinfection byproducts ${ }^{20-22}$.

As DOC concentrations increase, so do the chemical inputs required to maintain drinking water quality. Some treatment facilities are challenged with aging infrastructure that was designed to treat acidified surface waters with low color $^{23}$. Those serving small, remote communities-including First Nation and Indigenous communities-may have particular difficulties in this regard ${ }^{24-28}$.

Conventionally, particulate and dissolved analyte fractions are separated by filtration at $0.45 \mu \mathrm{m}$. Colloids-dispersed particles $1-1000 \mathrm{~nm}$ in at least one dimension ${ }^{29}$ - have not often been considered a unique size fraction. Colloids have been measured in the past by ultrafiltration ${ }^{30}$, size-exclusion chromatography ${ }^{31}$, and field-flow fractionation (FFF $)^{32}$. Flow FFF, a subtype, separates colloids based on hydrodynamic diameter. Separation is typically paired with online detection by UV/visible light absorbance, light scattering, or mass spectrometry ${ }^{33,34}$. Field-flow fractionation has been used to characterize colloid interactions with trace elements in surface waters ${ }^{34-36}$, demonstrating that DOM and iron-based colloids are major metal carriers.

Here, we investigate the relationship between DOM and metal colloids in six lakes representing a range of DOC levels characteristic of Nova Scotia, a region whose surface waters are browning significantly ${ }^{23,37,38}$. We determined elemental composition as a function of size using flow FFF with UV absorbance and ICP-MS detection. We supplemented these data with fluorescence spectra and a suite of conventional water quality metrics. We sought to determine the abundance and relative importance of larger iron-rich, primarily inorganic colloids and smaller DOM colloids in browning lakes, with the hypothesis that high DOC lakes with wetlands in their catchments would exhibit the strongest browning trends and have the highest concentrations of trace metals bound to colloids. These data have implications for browning drinking water supplies, especially those serving remote or vulnerable populations.

\section{RESULTS AND DISCUSSION Water quality}

The six lakes in our sample fall into two broad categories based on their typical DOC concentrations (Table 1). The low DOC lakesAlbro, Bayers, and Chocolate Lakes-had a median DOC concentration of $2.5 \mathrm{mg} \mathrm{L}^{-1}$ (range: $0.34-5.9$ ). The high DOC lakes-Frasers Lake, Long Lake, and Powers Pond-had a median of $7 \mathrm{mg} \mathrm{L}^{-1}$ (5.9-8.7). TOC and DOC were comparable, with a median difference of $0.2 \mathrm{mg} \mathrm{L}^{-1}$; most of the organic carbon in these lakes is "dissolved" $(<0.45 \mu \mathrm{m})$.

${ }^{1}$ Centre for Water Resources Studies, Department of Civil \& Resource Engineering, Dalhousie University, 1360 Barrington St., Halifax, Nova Scotia B3H 4R2, Canada. ${ }^{2}$ These authors contributed equally: Lindsay E. Anderson, Benjamin F. Trueman, Dewey W. Dunnington. ${ }^{凶}$ email: benjamin.trueman@dal.ca 
Table 1. Water quality summary of the study lakes (April-September 2019).

\begin{tabular}{|c|c|c|c|c|}
\hline Lake type & Parameter & Median & Range & Units \\
\hline \multirow[t]{18}{*}{ High DOC } & $\mathrm{Al}$ & 0.18 & $0.16-0.24$ & $\mathrm{mg} \mathrm{L}^{-1}$ \\
\hline & $\mathrm{BIX}$ & 0.51 & $0.47-0.53$ & - \\
\hline & $\mathrm{Ca}$ & 3.8 & $2.1-5.1$ & $\mathrm{mg} \mathrm{L}^{-1}$ \\
\hline & Color & 69 & $55-110$ & PtCo \\
\hline & $\mathrm{Cu}$ & 0.0012 & $0.001-0.0013$ & $\mathrm{mg} \mathrm{L}^{-1}$ \\
\hline & DOC & 7 & $5.9-8.7$ & $\mathrm{mg} \mathrm{L}^{-1}$ \\
\hline & $\mathrm{Fe}$ & 0.12 & $0.091-0.16$ & $\mathrm{mg} \mathrm{L}^{-1}$ \\
\hline & HIX & 14 & $9-19$ & - \\
\hline & Humic-like & 67 & $67-68$ & $\begin{array}{l}\% \text { of total } \\
\text { fluorescence }\end{array}$ \\
\hline & $\mathrm{Mn}$ & 0.029 & $0.019-0.04$ & $\mathrm{mg} \mathrm{L}^{-1}$ \\
\hline & $\mathrm{P}$ & 0.084 & $0.019-0.18$ & $\mathrm{mg} \mathrm{L}^{-1}$ \\
\hline & $\mathrm{pH}$ & 6 & $5.4-6.1$ & - \\
\hline & Protein-like & 1.1 & $0.92-1.4$ & $\begin{array}{l}\% \text { of total } \\
\text { fluorescence }\end{array}$ \\
\hline & SUVA & 4.9 & $4.3-5.7$ & $\mathrm{~L} \mathrm{mg}^{-1} \mathrm{~m}^{-1}$ \\
\hline & TOC & 8 & $5.9-11$ & $\mathrm{mg} \mathrm{L}^{-1}$ \\
\hline & Turbidity & 1.1 & $0.26-2$ & NTU \\
\hline & $U$ & $<\mathrm{MDL}$ & $<M D L-0.16$ & $\mu g \mathrm{~L}^{-1}$ \\
\hline & $U_{254}$ & 0.37 & $0.28-0.51$ & $\mathrm{~cm}^{-1}$ \\
\hline \multirow[t]{18}{*}{ Low DOC } & Al & 0.048 & $0.0082-0.057$ & $\mathrm{mg} \mathrm{L}^{-1}$ \\
\hline & $\mathrm{BIX}$ & 0.7 & $0.22-0.96$ & - \\
\hline & $\mathrm{Ca}$ & 13 & $8.6-15$ & $\mathrm{mg} \mathrm{L}^{-1}$ \\
\hline & Color & 8.3 & $0-25$ & PtCo \\
\hline & $\mathrm{Cu}$ & 0.001 & $0.00096-0.0034$ & $\mathrm{mg} \mathrm{L}^{-1}$ \\
\hline & DOC & 2.5 & $0.34-5.9$ & $\mathrm{mg} \mathrm{L}^{-1}$ \\
\hline & $\mathrm{Fe}$ & 0.037 & $0.025-0.12$ & $\mathrm{mg} \mathrm{L}^{-1}$ \\
\hline & HIX & 3.7 & $0.77-6.4$ & - \\
\hline & Humic-like & 62 & $42-65$ & $\begin{array}{l}\% \text { of total } \\
\text { fluorescence }\end{array}$ \\
\hline & $\mathrm{Mn}$ & 0.15 & $0.032-0.37$ & $\mathrm{mg} \mathrm{L}^{-1}$ \\
\hline & $\mathrm{P}$ & 0.27 & $0.17-0.42$ & $\mathrm{mg} \mathrm{L}^{-1}$ \\
\hline & $\mathrm{pH}$ & 6.1 & $5.3-7$ & - \\
\hline & Protein-like & 2.9 & $2.2-13$ & $\begin{array}{l}\% \text { of total } \\
\text { fluorescence }\end{array}$ \\
\hline & SUVA & 2.4 & $0.89-14$ & $\mathrm{~L} \mathrm{mg}^{-1} \mathrm{~m}^{-1}$ \\
\hline & TOC & 2.6 & $0.31-5.3$ & $\mathrm{mg} \mathrm{L}^{-1}$ \\
\hline & Turbidity & 0.96 & $0.25-3.7$ & NTU \\
\hline & $U$ & $<\mathrm{MDL}$ & $<\mathrm{MDL}-<\mathrm{MDL}$ & $\mu g \mathrm{~L}^{-1}$ \\
\hline & $U_{254}$ & 0.07 & $0.003-0.14$ & $\mathrm{~cm}^{-1}$ \\
\hline
\end{tabular}

Element concentrations represent $0.45 \mu \mathrm{m}$-filtered samples. In some samples, uranium was below its detection limit (MDL) for direct ICP-MS quantification of $0.08 \mu \mathrm{g} \mathrm{L}^{-1}$. Data were collected in 2019 (Table 2).

Median true color was 8.3 (range: $0-25)$ and 69 PtCo (55-110) in the low and high DOC lakes, respectively. Fluorescence was greater in the high DOC lakes and was generally dominated by humic and fulvic-like fluorophores (Fig. 1); protein-like fluorescence comprised a relatively minor component. The fraction of total fluorescence attributable to humic-like fluorophores was greater in high DOC lakes (67-68\%) than in low DOC lakes (42-65\%). The trend in protein-like fluorescence was opposite: the fractional fluorescence attributable to proteins was greater in the low (2.2-13\%) relative to the high DOC lakes (0.92-1.4\%).
Humification indices (HIX) ranged from 9-19 in the high DOC lakes, with a median of 14 . This suggests the occurrence in these lakes of high molecular weight, strongly aromatic DOM of terrestrial origin ${ }^{39,40}$. Humification indices ranged from $0.77-6.4$ in the low DOC lakes, with a median of 3.7. This implies that autochthonous DOM was present in samples yielding HIX in the lower half of this range $(H I X<4)^{39}$. Consistent with the HIX, median biological indices (BIX) were greater in the low compared to the high DOC lakes ( 0.7 vs. 0.51$)$. These values imply low DOM production across all lakes, although the differences among lakes suggest a greater fraction of DOM in the low DOC lakes was of autochthonous origin ${ }^{39,40}$.

Specific UV absorbance-SUVA, the ratio of $U_{254}$ to DOC-is highly correlated with the percent aromaticity of $\mathrm{DOM}^{41}$. The high DOC lakes had a median SUVA of $4.9 \mathrm{~L} \mathrm{mg}^{-1} \mathrm{~m}^{-1}$ (range: 4.3-5.7) which accords with high $\mathrm{HIX}$ and the presence of wetlands in the lake catchments. The low DOC lakes had a median SUVA of $2.4 \mathrm{~L} \mathrm{mg}^{-1} \mathrm{~m}^{-1}(0.89-14)$, lower HIX, and no wetlands in their catchments.

Consistent with regional trends ${ }^{23,38}$, most of the study lakes have browned significantly in the past three decades based on historical data (1991-2011) ${ }^{42,43}$ and those collected for this study (2019). The overall browning trend in the high DOC lakes is summarized in Fig. 2 via time series of true color, DOC, and the first principal component describing variation in color and DOC as a summary metric for colored DOM (trends for each lake are reported in Supplementary Table 1 and Supplementary Fig. 1). Over the period 1991-2019, linear regression slopes describing variation in color ranged from $0.96-1.94$ and $-0.29-0.55{\mathrm{PtCo} \mathrm{yr}^{-1}}^{-1}$ in the high and low DOC lakes, respectively. Trends in DOC ranged from $0.06-0.12$ and $0.00-0.13 \mathrm{mg} \mathrm{C} \mathrm{L}^{-1} \mathrm{yr}^{-1}$. While browning was most prominent in the high DOC lakes, DOC and color increased in all but Chocolate Lake, which exhibited a decreasing color trend

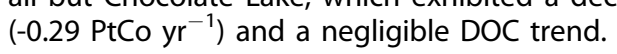

\section{Colloid characterization}

Fractograms (i.e., analyte intensities as functions of time) were generally bi- or tri-modal, with peaks at approximate retention times of 13 (P1), 20 (P2), and 29 (P3) minutes (Supplementary Fig. 2). $P 1$ and $P 2$ correspond to approximate molecular weights of 1 and $1000 \mathrm{kDa}$, respectively (Fig. 3 and Supplementary Fig. 3). P3 was estimated at $>2000 \mathrm{kDa}$, but P3 occurred beyond the calibration range $(0.69-2000 \mathrm{kDa})$ and represents signal acquired without a cross-flow.

Peaks at 1 and $1000+\mathrm{kDa}$ represent primarily organic and inorganic colloids ${ }^{44,45}$, respectively. The majority of UV absorbance at $254 \mathrm{~nm}\left(\mathrm{UV}_{254}\right)$ was due to P1 $(1 \mathrm{kDa})$, which, consistent with previous work ${ }^{45,46}$, likely represents organic macromolecules. P2 and P3 were rich in iron, which agrees with previous reports of largely inorganic, transition metal oxide-based colloids in this size range ${ }^{45}$. Iron also occurred at $1 \mathrm{kDa}$, suggesting that it was complexed with colloidal DOM. P3, at $29 \mathrm{~min}$, was relatively prominent in the manganese fractograms, which also featured peaks at $20 \mathrm{~min}(\mathrm{P} 2$, $1000 \mathrm{kDa}$ ) but only negligibly at $13 \mathrm{~min}$ (P1, $1 \mathrm{kDa}$ ). That is, manganese was identified in inorganic colloids-or in dissolved forms-but not to any significant degree as an adsorbate on DOM colloids in P1. Copper and aluminum occurred primarily in P1, implying that these elements were largely bound to DOM.

Semiquantitive aluminum, iron, copper, and uranium concentrations in P1 (FFF data) were correlated with DOC, UV 254 , true color, and the humification index (HIX) (Fig. 4b). That is, concentrations of these metals at $1 \mathrm{kDa}$ were greater in the three high DOC lakes than in the three low DOC lakes. The high DOC lakes also scored higher on the first principal component (PC1, Fig. 4a), which can be interpreted as an overall intensity index for the fractogram data (Fig. 4c). PC2-the second principal component-contrasts colloids in the 1 and $1000+\mathrm{kDa}$ nominal 

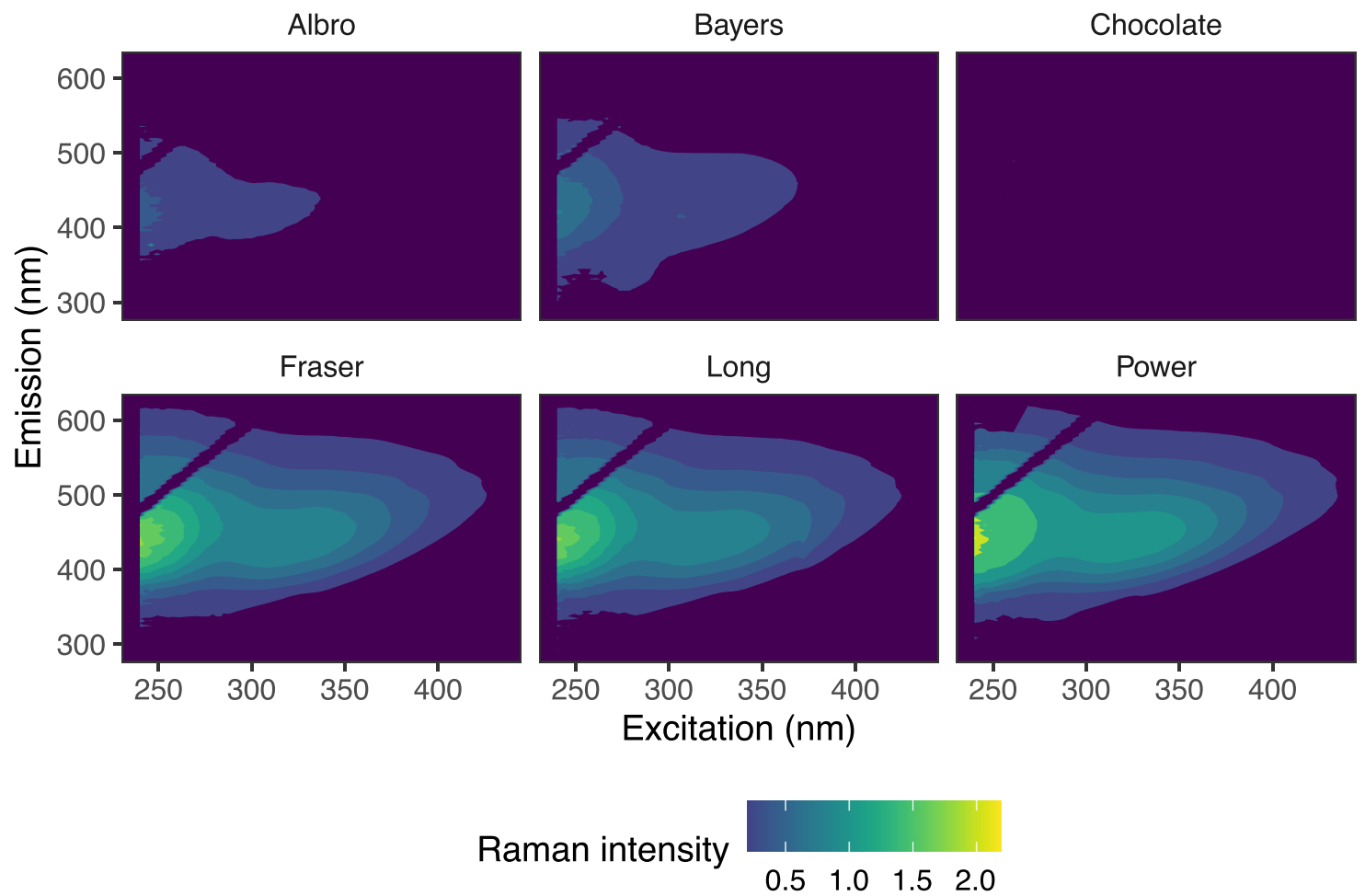

Fig. 1 Fluorescence excitation-emission matrices (EEMs) representing the six lakes in the dataset. The Raman intensity at each excitationemission coordinate represents an average of multiple EEMs. Data were collected in 2019 (Table 2).

size fractions (P1 and P2-P3), with negative scores representing samples where larger colloids are disproportionately represented (Fig. 4c). In the high DOC lakes, scores on PC2 became more negative from spring to summer, reflecting increasing dominance of P2 and P3. Likewise, negative scores on PC2 for samples representing Bayers Lake are consistent with the high intensity of colloidal $\mathrm{Fe}$ in that lake relative to the other low DOC lakes. The first two components together accounted for $89 \%$ of total variation in the FFF data (Supplementary Fig. 4).

We estimated the contribution of each fraction to the overall size distribution by deconvolution; fractograms were approximated as the sum of skewed Gaussians ${ }^{46}$. A median $81 \%$ of UV absorbance was accounted for in the three high DOC lakes by P1 (range: $35-89 \%$, Fig. 5). The remainder was explained by $\mathrm{P} 2$ and P3. In the low DOC lakes, larger colloids (P2-P3) dominated absorbance fractograms: the respective median shares were $37 \%$ and $22 \%$, while $\mathrm{P} 1$ accounted for a median of $32 \%$.

Iron fractograms representing the high DOC lakes were dominated by $\mathrm{P} 2$, with a median share of $67 \%$. P1 and P3 accounted for a median of 26 and $6 \%$ of total colloidal iron, respectively. In the low DOC lakes, P2 iron was even more dominant, with a median signal share of $72 \%$, and P3 replaced P1 as the second-most abundant fraction with a median share of $20 \%$. This pattern was particularly evident in Bayer's Lake, which had significant concentrations of iron, and to a lesser extent copper, in P2 and P3 (Fig. 3).

Aluminum in the high DOC lakes occurred primarily in P1 (median: 55\%), although P2 was sometimes significant (median: $43 \%)$. In the low DOC lakes, P2 aluminum was more prominent, accounting for a median share of $58 \%$ among samples where it was detected. High DOC lakes were richer in manganese, but unlike iron and aluminum, it was present almost exclusively in larger colloids (P2-P3, 1000+ $\mathrm{kDa}$ ) with a median of $1 \%$ attributable to $\mathrm{P} 1$.

\section{Primarily organic ( 1 kDa) colloids (P1)}

Previous studies ${ }^{44,47}$ have reported a bi-modal colloid distribution in surface waters, where the smaller peak comprises DOM and DOM-metal complexes (approximately $1-10 \mathrm{~nm}$ ) and the larger, transition metal oxides $(>50 \mathrm{~nm})$ with adsorbed DOM and trace metals. Consistent with these results, our study lakes contained two primary colloid fractions: a metal-DOM peak (P1) at approximately $1 \mathrm{kDa}$ and an iron-rich, primarily inorganic peak (P2) at approximately $1000 \mathrm{kDa}$. These colloids were present at significantly higher concentrations in the high DOC lakes.

The molecular weight estimate for $\mathrm{P} 1$ is consistent with the reported range for humic and fulvic acids ${ }^{48}$ and DOM extracts from surface waters ${ }^{45}$. It agrees with previous work showing that these colloids are typically less than $10 \mathrm{kDa}^{48,49}$. Here, a substantial fraction of colloidal iron (up to 57\%) was bound to DOM (P1). In a majority of samples, greater than $50 \%$ of colloidal aluminum, copper, and uranium was also associated with DOM. This is consistent with mechanistic studies of metal binding to the phenolic and carboxylic functional groups that are well-represented in high molecular weight organic matter ${ }^{48,50}$.

In Nova Scotia's surface waters, aluminum is often correlated with $\mathrm{DOC}^{12}$, and Al-DOM complexation is relatively well documented ${ }^{51-53}$. Aluminum in $\mathrm{P} 1$ likely explains the elevated levels in the high DOC study lakes. These lakes have $\mathrm{pH}$ near the solubility minimum of aluminum hydroxide-a possible solubilitycontrolling phase ${ }^{54}$-and without considering colloids, predicted solubility would be low (Table 1). Al-DOM complexation also explains the correlation between semiquantitative P1 aluminum concentrations and various DOM metrics (Fig. 4b).

Iron in P1 was also higher in the high DOC study lakes, which is consistent with the expected binding of iron to DOM colloids. Complexation provides a partial explanation for high "dissolved" iron (Table 1). Considering only simple inorganic ligands, ferric iron is highly insoluble above $\mathrm{pH} 4$, with a typical equilibrium concentration below $1 \mu \mathrm{M}^{55}$. In the presence of complexing 

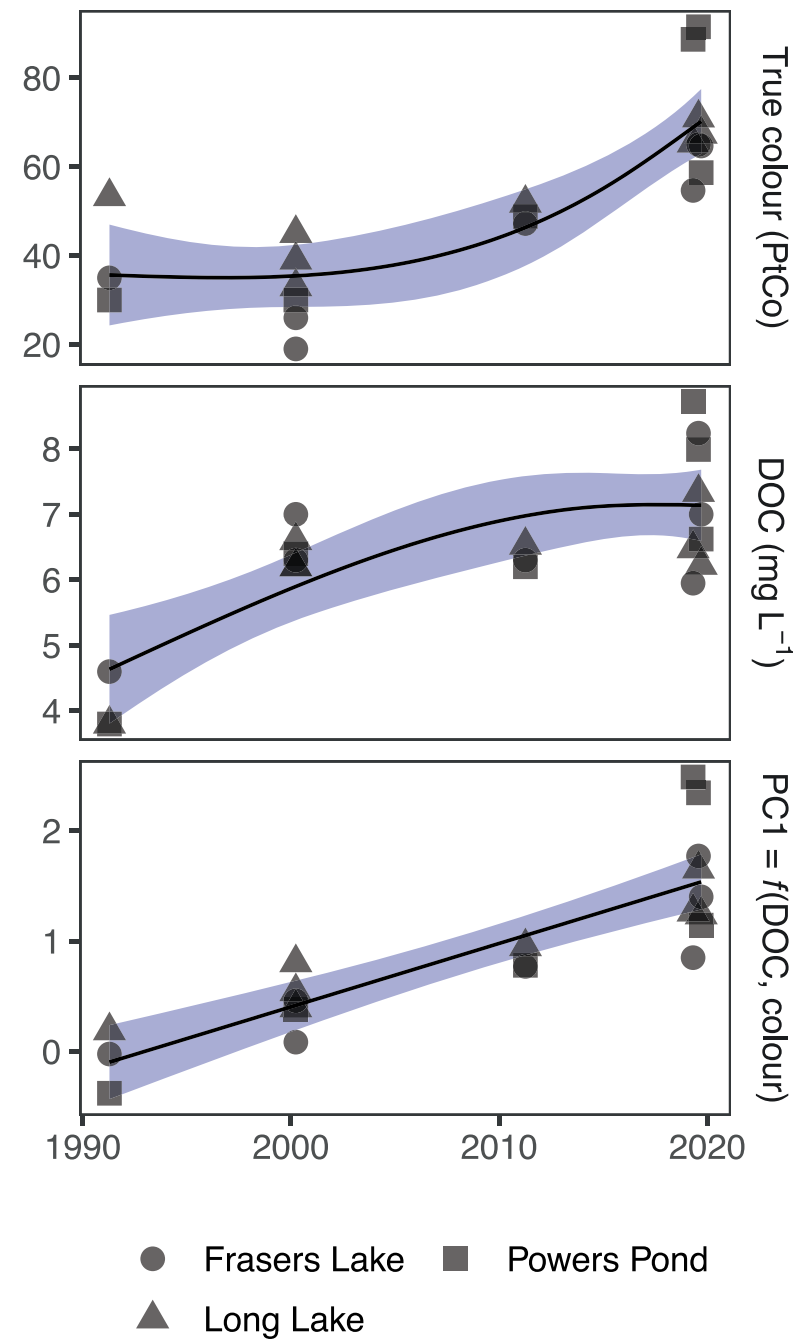

Fig. 2 Water quality trends in the high DOC study lakes. The first principal component ( $\mathrm{PC1}, 70 \%$ of total variance) describing variation in DOC and color is used as a summary metric for colored DOM; PC1 scales with the sum of (standardized) DOC and color (PC1 $=0.7 \mathrm{DOC}+0.7$ color). The solid lines in all panels represent cubic regression splines fit to the data, and the shaded regions define a pointwise $95 \%$ confidence interval on the fitted values. Data before 2019 are due to Clement et al. ${ }^{42}$ or Clement and Gordon ${ }^{43}$ and were otherwise collected as part of this study (Table 2).

organic ligands, however, ferric iron solubility can be much greater.

Similar patterns have been described elsewhere: Cuss et al. ${ }^{56}$ reported that aluminum was present exclusively in ionic/small forms or associated with DOM colloids in the Athabasca River and its tributaries. Iron was also associated with DOM colloids, albeit to a lesser degree. Dupré et al. ${ }^{57}$ fractionated river water by ultrafiltration, finding that organic colloids were important for aluminum and iron transport. Baalousha et al. ${ }^{58}$ detected aluminum and DOM in a common fraction sized below $10 \mathrm{~nm}$ by FFF, and Morrison and Benoit $^{59}$ showed that at least some aluminum was bound to organic colloids in freshwater samples from six Connecticut rivers. Several studies ${ }^{35,36,56,59,60}$ have found that copper and uranium are primarily associated with organic colloids.

While our data provide no clear evidence of Mn-DOM complexation at $1 \mathrm{kDa}$, Cuss et al. $^{56}$ attributed at least a minor fraction of colloidal $\mathrm{Mn}$ to DOM in all samples. Lyvén et al. ${ }^{35}$ attributed $70 \%$ of manganese in a freshwater sample to carbonbased colloids and Baalousha et al. ${ }^{34}$ found that manganese was bound to DOM colloids less than $10 \mathrm{~nm}$ in diameter. Other studies $^{36,56,58,61}$ have reported manganese association with ironbased colloids, which is more consistent with our results.

It is also possible that adsorption sites on DOM were largely occupied by aluminum and iron, which were present at much higher levels than manganese. But the capacity for DOM to bind these metals may be increasing over time: positive trends in surface water DOC have often accompanied a shift to more hydrophobic, aromatic, and colored DOM with a greater density of metal binding sites ${ }^{62,63}$.

\section{Primarily inorganic (1000+ kDa) colloids (P2-P3)}

Given the study lakes' water chemistry, DOM-stabilized iron (III) (oxyhydr)oxides were expected to account for the iron in P2 and $\mathrm{P} 3^{19,36}$. Stabilization occurs when DOM, particularly high molecular weight macromolecules, partitions to iron colloids via surface complexation. Negatively charged functional groups and organic polymer chains extend outward into the water phase, providing electrostatic and steric repulsion ${ }^{19,64}$. In light of its stabilizing effect $^{19}$, adsorbed DOM might account for variation in the size of iron-rich colloids, allowing aggregation and growth at lower concentrations ${ }^{64}$. Previous work ${ }^{36}$ has described a positive shift in the size distribution of colloidal iron in moderate, relative to high, DOC surface waters.

Here, all elements were associated to some degree with large, Fe-rich colloids ( $1000+\mathrm{kDa}, \mathrm{P} 2-\mathrm{P3})$, albeit only a small fraction in the case of uranium and copper. A significant fraction of total colloidal aluminum was present in P2-P3, in contrast to the results of Cuss et al. ${ }^{56}$, who did not report any significant association of aluminum with large Fe-rich colloids.

Manganese in P2 likely occurred as (oxyhydr)oxides or mixed iron/manganese phases ${ }^{65}$. In surface waters, manganese occurs in three oxidation states: soluble $\mathrm{Mn}$ (II) (stable in anoxic waters), $\mathrm{Mn}$ (III) (e.g., as $\mathrm{MnOOH}$ ), and $\mathrm{Mn}(\mathrm{IV})$ (e.g., as $\left.\mathrm{MnO}_{2}\right)^{65}$. A range of manganese (oxyhydr)oxides form in well-oxygenated waters at the lake surface, unless seasonal mixing distributes dissolved $\mathrm{Mn}$ (II) across the water column ${ }^{65}$. Stratification of the study lakes typically peaks in late summer or early fall, which may explain the greater magnitude of P2 in July and September as well as the apparent presence of ionic manganese (void volume, P0) in June when the lakes would have been more fully mixed (Fig. 3). Consistent with our data, Cuss et al. ${ }^{56}$ reported that large Fe-rich colloids accounted for a substantial fraction of $\mathrm{Mn}$ in the Athabasca River.

\section{Implications for drinking water treatment}

The browning trends reported here fit with a pattern of increasing DOC, iron, aluminum, and color in the region's lakes ${ }^{23,37,38}$. These trends may have adverse impacts on drinking water quality as lakes become more difficult to treat ${ }^{23,66-68}$. In one of the region's most important drinking water supplies, for instance, source water color increased nearly four-fold over 16 years (1999-2015), necessitating a proportional increase in coagulant addition to maintain treated water quality ${ }^{23}$.

If colloids are not removed during treatment, they facilitate lead release from legacy plumbing via complexation or partitioning to DOM-stabilized metal (oxyhydr)oxides ${ }^{24,46,69-72}$. Emerging evidence suggests that colloidal lead is poorly removed by point-of-use treatment systems $s^{73,74}$. Furthermore, aluminum and manganese are the subjects of current or proposed regulations or monitoring requirements ${ }^{75,76}$. Treatment facilities that are ill-equipped to manage increasing metal and DOM loads in drinking water supplies may fail to meet increasingly stringent drinking water guidelines.

This work highlights the importance of DOM removal in drinking water treatment and could inform future treatment plant 


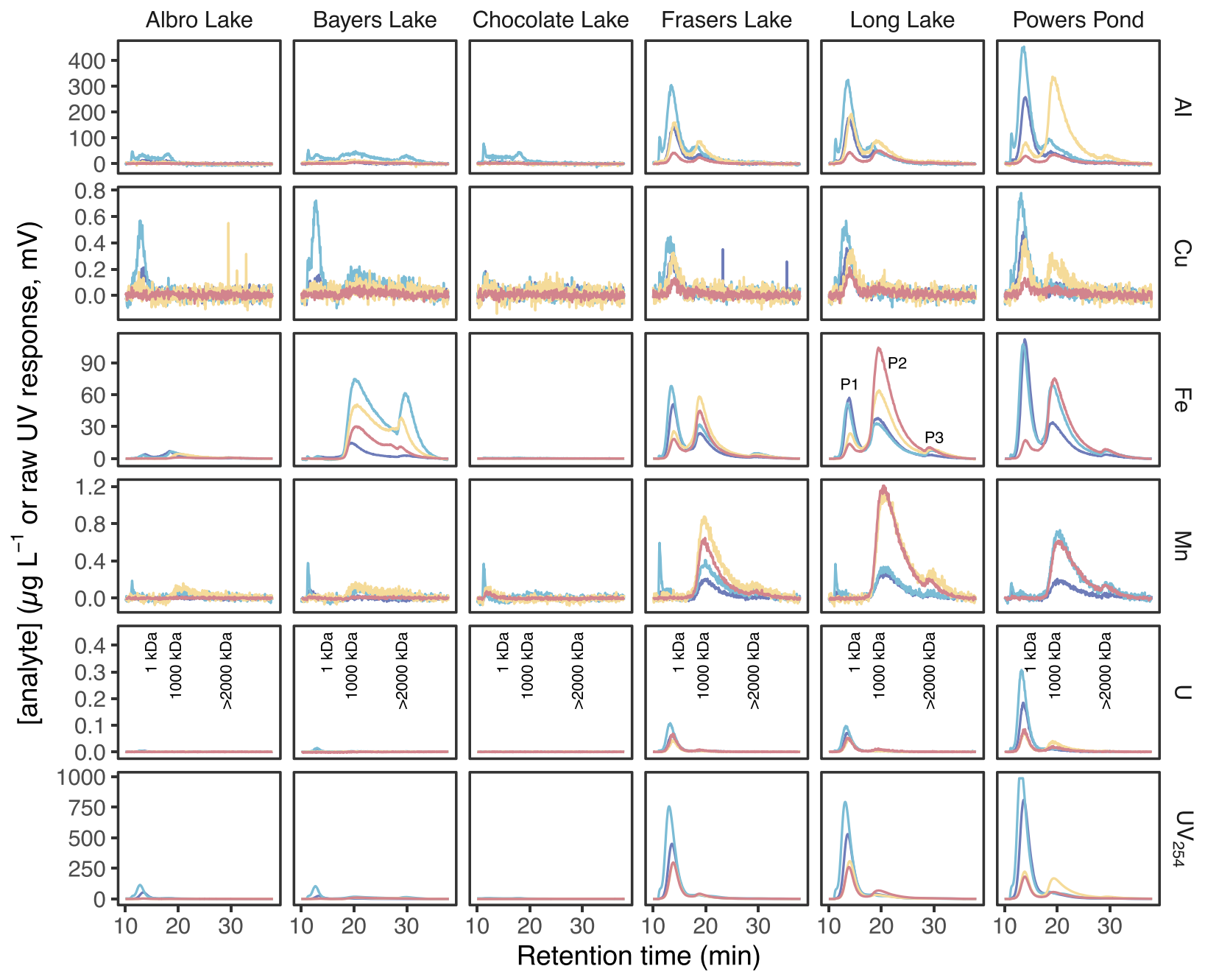

- Apr $26-\operatorname{Jun} 10-\operatorname{Jul} 30-\operatorname{Sep} 15$

Fig. 3 Semiquantitative fractograms representing the six study lakes. The July Fe and Mn data representing Powers Pond are omitted for clarity of presentation due to anomalously high concentrations. Data were collected in 2019 (Table 2).

design. Conventional treatment practice focuses on removing metals and DOM independently. Trace metals are typically removed by oxidation and DOM is removed by coagulation, sedimentation, and filtration. The metal-DOM binding we report here suggests that treatment facilities should adapt to brownification by optimizing DOM removal first. These facilities may see significant reductions in metals as a secondary benefit.

DOM increases are expected to continue given the anticipated effects of climate change and the ongoing reductions in atmospheric acid deposition ${ }^{3}$. With continued browning, we can expect increases in DOM-associated metals, as well as the concomitant impacts on ecosystem services. Anticipated climate warming may be particularly detrimental to source waters that are browning $^{68,77}$. The positive effect of temperature on cyanobacteria growth and toxin production is strongly amplified when the humic content of water is high ${ }^{78}$. Since cyanobacteria are bettersuited to low-light environments than most phytoplankton, light attenuation by DOM may offer cyanobacteria a competitive advantage ${ }^{78,79}$, further complicating water treatment.

Future monitoring and management plans, then, would better serve the public by characterizing DOM and iron-rich, primarily inorganic colloids that contribute to adverse water quality outcomes, especially in catchments that include wetlands. Such plans could inform process design and drinking water source selection. In the Canadian context, this is of particular importance for First Nation and Indigenous communities already challenged with drinking water safety issues ${ }^{24-28}$. Inadequate water treatment infrastructure and operational issues make such communities especially vulnerable to the impacts of brownification.

\section{METHODS}

\section{Study area and sampling}

We collected water samples from six lakes in the Halifax Regional Municipality to characterize the variability of colloids over time and among lakes with different characteristics (Supplementary Fig. 5). We chose three lakes with low DOC concentrations (Albro Lake, Bayers Lake, and Chocolate Lake) and three lakes with high DOC concentrations (Frasers Lake, Long Lake, and Powers Pond). All six lakes were included in a sampling program of Halifax-area lakes conducted in 1991,2000, and 2011 (Table 2) (2,43 $^{\text {. The }}$ catchments of Frasers Lake, Long Lake, and Powers Pond are 2-5\% wetland, while Albro, Bayers, and Chocolate Lakes do not have wetlands in their catchments. The catchments of Bayers and Chocolate Lakes are 
(a)

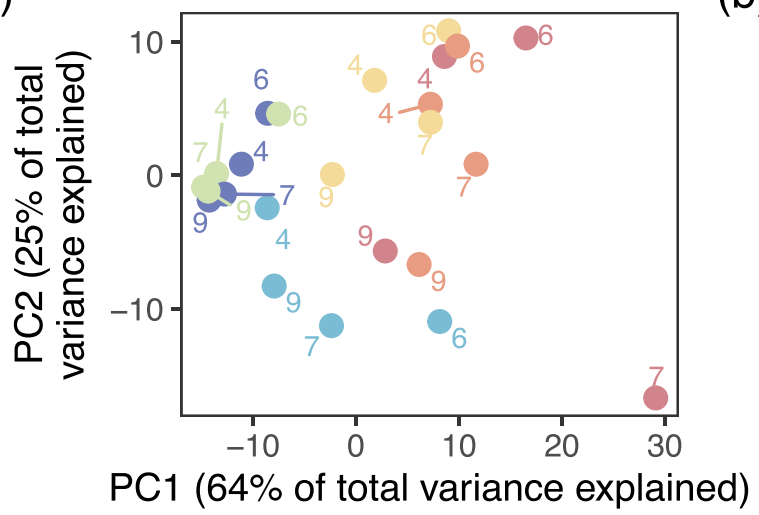

(b)

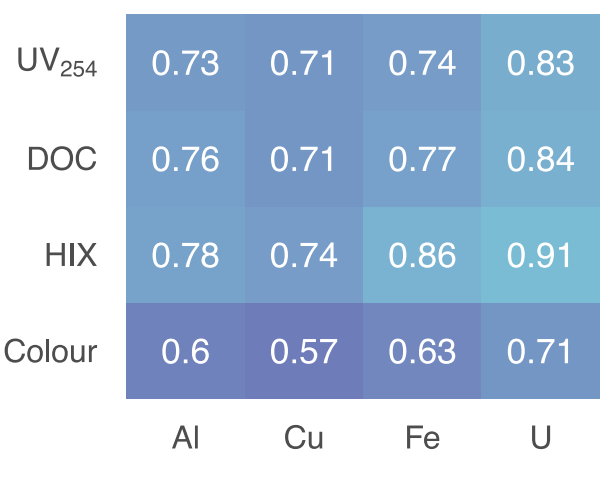

(c)

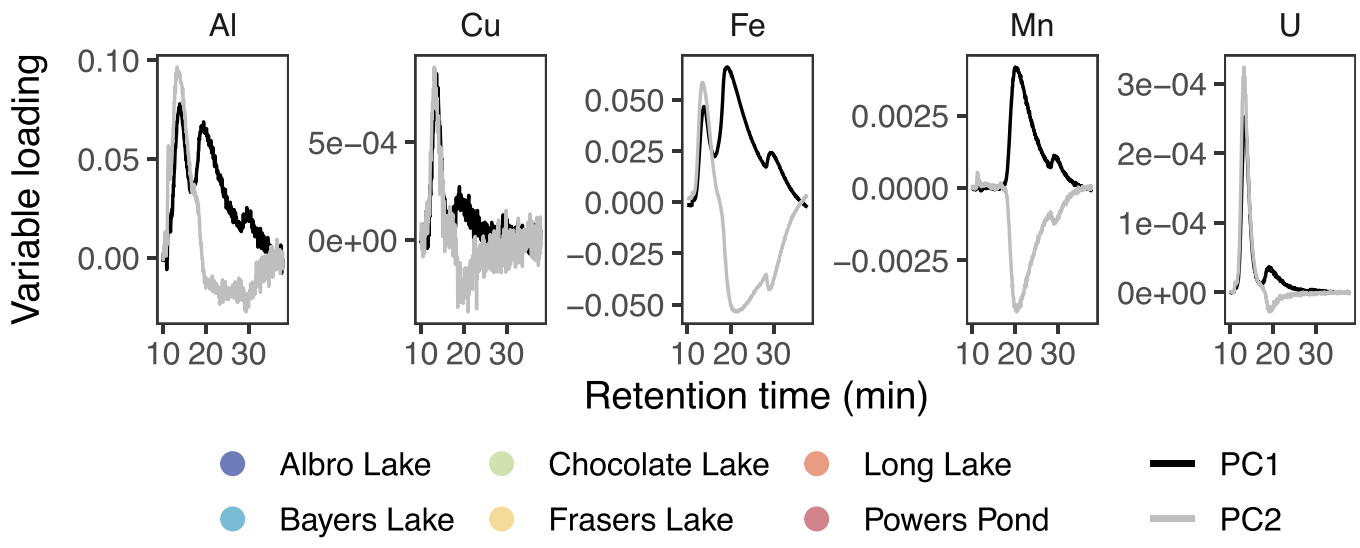

Fig. 4 Multivariate analysis of lake water chemistry. a FFF data representing all six study lakes, projected onto the space spanned by the first two principal components. Sample month is annotated with Arabic numerals. b Except for manganese, semiquantitative element concentrations in the $1 \mathrm{kDa}$ size fraction were correlated with $\mathrm{UV}_{254}$, true color, DOC, and HIX (Table 1). Values represent Spearman rank correlation coefficients. c Variable loadings (eigenvectors), separated by element. Data were collected in 2019 (Table 2).

underlain in part by the Cunard Formation, which has produced uncharacteristically acidic surface waters following disturbance of the bedrock due to commercial and industrial activity ${ }^{80}$.

We collected samples every six weeks from spring turnover until the time of strongest stratification (September). Samples were collected from the mixed layer ( $0.5 \mathrm{~m}$ depth) at the approximate center of each lake from an inflatable kayak. We used acid-washed bottles (1 L HDPE) for sample collection and stored samples at $4{ }^{\circ} \mathrm{C}$ before analysis. The median time elapsed between collection and analysis was 10 days (range: 1-19 days).

\section{Field-flow fractionation}

We generated element-specific size distributions for each water sample using asymmetric flow field-flow fractionation (FFF). Details of our FFF method are available elsewhere ${ }^{46}$. In brief, we filtered a $10 \mathrm{~mL}$ aliquot from each sample using a $0.45 \mu \mathrm{m}$ cellulose nitrate membrane immediately before analysis. Each filter was cleaned with $20 \mathrm{~mL}$ of ultrapure water followed by $20 \mathrm{~mL}$ of sample. We separated each sample using an asymmetric flow FFF system (PostNova AF2000 Multiflow) with a $300 \mathrm{Da}$ polyethersulfone membrane and a manual injection valve with a $1 \mathrm{~mL}$ polyether ether ketone (PEEK) sample loop. The system was coupled first to a UV-vis detector (Shimadzu SPD-20A) and then to a quadrupole ICP-MS (Thermofisher X series II). During separation, dissolved organic matter was monitored by measuring absorbance at a wavelength of $254 \mathrm{~nm}$. The mobile phase for all separations was $50 \mathrm{mM}$ tris- $\mathrm{HCl}(\mathrm{pH}$ 7.1). This represents an upper bound on the $\mathrm{pH}$ of the study lakes, and while large changes in the chemical and physical states of elements during separation were not expected, pH-dependent effects on colloids cannot be ruled out. Moreover, continuous re-equilibration during focusing may have impacted the stability of weakly-bound trace elements, resulting in differences between the in-situ and acquired size distributions.

The FFF procedure separated samples into three primary fractions, with approximate sizes of 1,1000 , and $>2000 \mathrm{kDa}$ (P1, P2, and P3, respectively) (Supplementary Fig. 2). The UV detector response in P2-P3 may be due at least in part to light scattering, but is not explained by carry-over from P1; we ensured this by separating Suwannee River natural organic matter at a concentration chosen to achieve a comparable detector response to that of Powers Pond (Supplementary Fig. 6). Aluminum, copper, and manganese fractograms featured a prominent void peak (P0), representing ionic forms of these elements and unfocused sample material.

We used an initial cross-flow of $2.5 \mathrm{~mL} \mathrm{~min}^{-1}$ and $10 \mathrm{~min}$ of focusing time. After focusing, the cross-flow was maintained for $6 \mathrm{~min}$ and then decayed linearly over $2 \mathrm{~min}$ to $0.1 \mathrm{~mL} \mathrm{~min}^{-1}$, separating free and organically complexed metals from larger iron-rich colloids. A second population of large colloids was detected after the cross-flow was set to zero at $28 \mathrm{~min}$. Analyte recoveries were estimated as the ratio of total integrated peak area with and without a cross-flow, as described elsewhere ${ }^{46}$. FFF separation recovered approximately 48, 24, 62, 39, and $45 \%$ of $\mathrm{Al}, \mathrm{Cu}, \mathrm{Fe}, \mathrm{Mn}$, and $\mathrm{U}$, respectively, from a sample representing Powers Pond. These estimates reflect losses of ionic and small forms of each element that occur by design, in addition to losses due to adsorption to the membrane (n.b., such non-ideal interactions may impact the relative importance of size fractions as described in the results section).

Recovery of $\mathrm{UV}_{254}$ was estimated using a sample of Suwannee River natural organic matter at $57 \%{ }^{46}$. Similar recoveries of DOM and metals have been reported previously for similar samples and separation conditions ${ }^{45,46}$, although recovery of iron was somewhat higher here. 


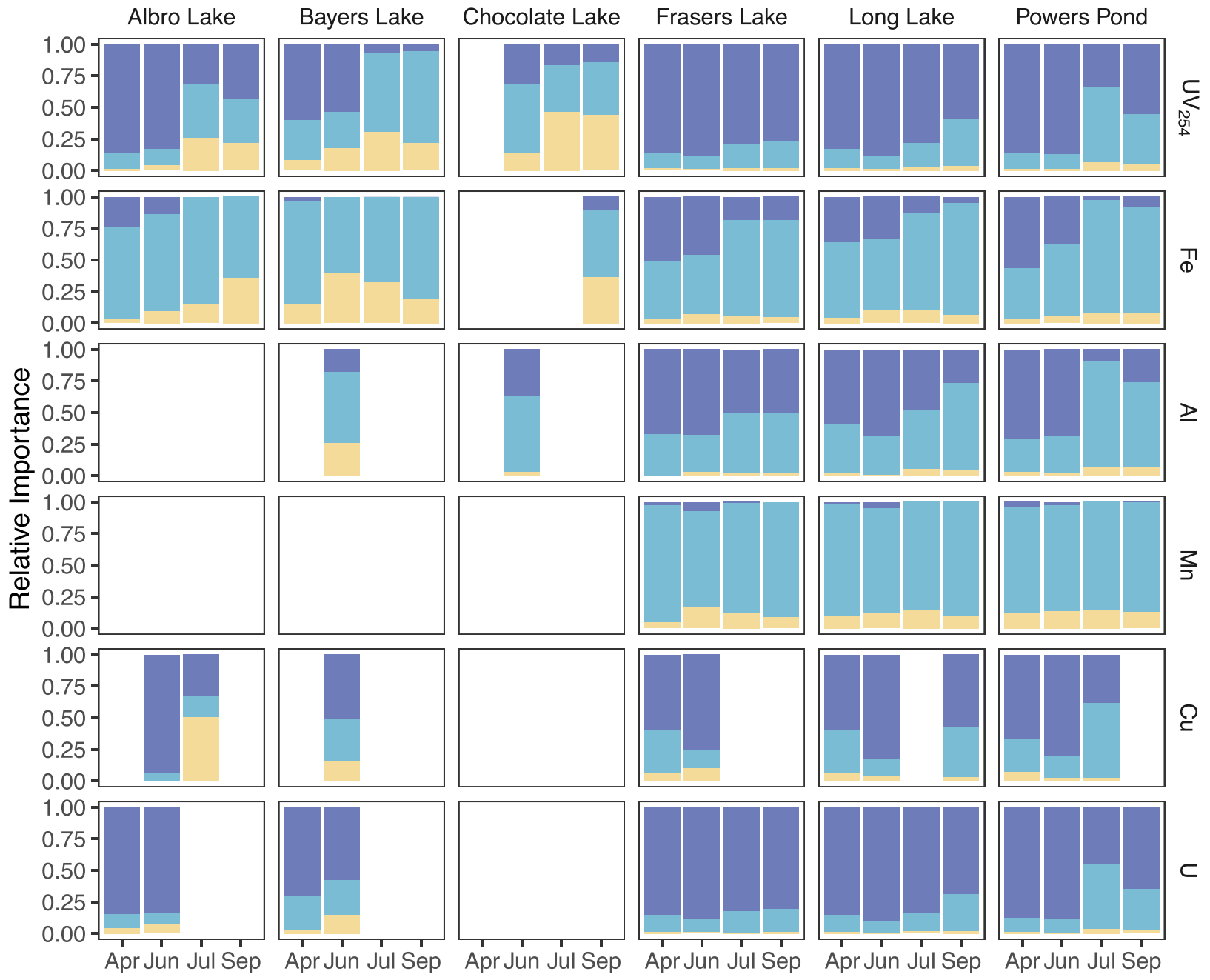

$1 \mathrm{kDa}$

$1000 \mathrm{kDa}$

$>2000 \mathrm{kDa}$

Fig. 5 Contribution of the nominal 1, 1000, and $>\mathbf{2 0 0 0}$ kDa size fractions to each fractogram, estimated by deconvolution. Fractograms with nonquantifiable peaks ( $<10$ times the baseline standard deviation) were omitted. Data were collected in 2019 (Table 2).

We calibrated the FFF system using bromophenol blue $(0.69 \mathrm{kDa})$ and blue dextran $(2000 \mathrm{kDa})$ at $590 \mathrm{~nm}$; tannic acid $(1.7 \mathrm{kDa})$ at $254 \mathrm{~nm}$; and ferritin $(440 \mathrm{kDa})$ and ovalbumin $(44 \mathrm{kDa})$ at $280 \mathrm{~nm}$. Linear decay of the crossflow necessitated a quadratic fit to the molecular weight (MW) calibration data: $\log _{10}(\mathrm{MW})=11.76-1.89 v_{\mathrm{r}}+0.07 v_{\mathrm{r}}^{2}\left(\mathrm{R}^{2}=0.98\right.$, where $v_{\mathrm{r}}$ is the retention volume).

FFF-ICP-MS data were acquired using a collision cell with a mixture of $7 \% \mathrm{H}$ in $\mathrm{He}$ to minimize the interference of ${ }^{40} \mathrm{Ar}^{16} \mathrm{O}$ on ${ }^{56} \mathrm{Fe}$. We calibrated the ICP-MS on each analysis day using multielement standards in $2 \%$ $\mathrm{HNO}_{3}$, containing $\mathrm{Al}, \mathrm{Mn}, \mathrm{Fe}, \mathrm{Cu}$, and $\mathrm{U}$ at $25,50,100,150$, and $250 \mu \mathrm{g} \mathrm{L}^{-1}$. Each was spiked with $50 \mu \mathrm{g} \mathrm{L}^{-1} \mathrm{Sc}$, In, and Tb as internal standards. Calibration curves yielded median $\mathrm{R}^{2}$ values (across all runs) of 0.9474 , $0.9999,0.9997,0.9999$, and 0.9998 , respectively. Quality control spikes in the same matrix $\left(75 \mathrm{\mu g} \mathrm{L}^{-1}\right)$ yielded $83.8,99.6,98.2,100.7$, and $101.6 \%$ recoveries of $\mathrm{Al}, \mathrm{Mn}, \mathrm{Fe}, \mathrm{Cu}$, and $\mathrm{U}$, respectively. An independentlyprepared spike at $40 \mu \mathrm{g} \mathrm{L}^{-1}$ yielded $80.5,99.3,96.9$, and $100.3 \%$ recoveries of $\mathrm{Al}, \mathrm{Mn}, \mathrm{Fe}$, and $\mathrm{Cu}$. Standards were introduced to the nebulizer by means of the ICP-MS autosampler after mixing with FFF channel effluent via the mixing tee. Flow rates were similar between calibration and separation, differing by less than $10 \%$; we minimized this difference with adjustments to the peristaltic pump speed. Detection limits were estimated using the $3 \sigma$ method, with $\sigma$ calculated separately for the elution step of a total of six blanks collected on different analysis days ${ }^{81-83}$. Median detection limits for $\mathrm{Al}, \mathrm{Cu}, \mathrm{Fe}, \mathrm{Mn}$, and $\mathrm{U}$ were 10 (8), 0.1 (0.05), 0.4
(0.4), $0.06(0.08)$, and $0.002(6 \mathrm{e}-04) \mu \mathrm{g} \mathrm{L}^{-1}$, respectively (interquartile ranges in parentheses).

\section{Water chemistry analysis}

As a supplement to the FFF data, we measured the $\mathrm{pH}$, turbidity, and total organic carbon (TOC) content of unfiltered lake water samples. We characterized the optical properties (true color, $\mathrm{UV}_{254}$, fluorescence), DOC concentration, and elemental composition of filtered water samples. We filtered samples for non-FFF analysis using $0.45 \mu \mathrm{m}$ polysulfone membrane filters precleaned with $500 \mathrm{~mL}$ of ultrapure water.

Turbidity was measured on a laboratory turbidimeter (Hach 2100AN) and $\mathrm{pH}$ was measured using a benchtop unit (Accumet XL50, Fisher Scientific). True color and $U_{254}$ were measured on a UV-Vis spectrophotometer (Hach DR5000, Hach Company, Loveland, CO, methods 8025 and 10054, respectively). TOC and DOC samples were collected, headspace-free, in $40 \mathrm{~mL}$ clear glass vials and preserved with concentrated phosphoric acid to $\mathrm{pH}<2$. Vials were washed and then baked at $105^{\circ} \mathrm{C}$ for at least $24 \mathrm{~h}$ before use. TOC and DOC were quantified using a TOC-V CPH analyser with a Shimadzu ASIO-V autosampler and a catalytically-aided combustion oxidation non-dispersive infrared detector with a method detection limit of $0.08 \mathrm{mg} \mathrm{L}^{-1}$ (Shimadzu Corporation, Kyoto Japan) ${ }^{84}$.

Element concentrations in the bulk water samples were quantified by ICP-MS (Thermofisher X-series II) ${ }^{85}$, with instrument detection limits of 0.67 , 
Table 2. Summary of data collection and sources.

\begin{tabular}{lllll}
\hline Collected in & Number of samples & Parameters & Appears in Figure & Source (reference \#) \\
\hline 2019 & 24 & FFF, pH, turbidity, TOC, DOC (18), color, EEM, UV 254, IPC-MS (6) & $1-5$ & This study \\
2011 & 6 & True color, DOC & 2 & 44 \\
2000 & 9 & True color, DOC & 2 & 43 \\
1991 & 4 & True color, DOC & 2 & 43 \\
\hline
\end{tabular}

Where the number of samples for a particular parameter differs from the number indicated in the left adjacent column, this number is indicated in parentheses.

$0.20,0.80,0.12$, and $0.08 \mu \mathrm{g} \mathrm{L}^{-1}$ for $\mathrm{Fe}, \mathrm{Cu}, \mathrm{Al}, \mathrm{Mn}$, and $\mathrm{U}$ (calculated from a series of 10 ultrapure water blanks in $2 \%$ nitric acid as $\sigma t_{9 r a}=0.01$ ). Samples were acidified with nitric acid to $\mathrm{pH}<2$ and held for at least $24 \mathrm{~h}$ before analysis.

A benchtop fluorometer (Horiba Aqualog) with excitation and emission ranges of $230-610 \mathrm{~nm}$ and $250-620 \mathrm{~nm}$, respectively, was used to generate all fluorescence excitation-emission matrices (EEMs). The instrument's integration interval and spectral resolution were $0.1 \mathrm{~s}$ and $3 \mathrm{~nm}$. Before acquiring data, an ultrapure water blank was used to measure the signal-tonoise ratio of the water Raman peak at $350 \mathrm{~nm}$ (excitation) and $397 \mathrm{~nm}$ (emission). Each EEM was processed by subtracting the blank, correcting inner filter effects, and removing 1 st and 2 nd order Raleigh scattering, as described elsewhere ${ }^{86}$. Intensities were normalized against the Raman water peak at an excitation wavelength of $350 \mathrm{~nm}$. The median time elapsed between collection and fluorescence analysis was 3 days (1-17 days).

Humification and biological indices were calculated for each EEM as described in Tedetti et al. ${ }^{39}$. The humification index (HIX) is the ratio $a / b$, where $a$ and $b$ are the integrated emission spectra from 434-480 to $300-344 \mathrm{~nm}$, respectively. Both were acquired at an excitation wavelength of $255 \mathrm{~nm}$. High HIX values (>10) are an indicator of aromatic DOM of terrestrial origin, whereas low HIX values $(<4)$ indicate autochthonous DOM. The biological index (BIX) is the ratio of fluoresence intensities at emission wavelengths of 380 and $430 \mathrm{~nm}$, both acquired at an excitation wavelength of $310 \mathrm{~nm}$. High BIX values $(>1)$ are an indicator of autochthonous $\mathrm{DOM}^{39}$.

Turbidity, true color, $\mathrm{UV}_{254}$, organic carbon, and elemental concentrations are reported as nephelometric turbidity units (NTU), true color units (platinum cobalt units, $\mathrm{PtCo}$ ), $\mathrm{cm}^{-1}$, and $\mathrm{mg} \mathrm{L}^{-1}$, respectively.

\section{Trend analysis}

We modeled the change in true color and DOC over time in the high DOC study lakes using cubic regression splines (equation 1), fit using the $\mathrm{mgcv}$ package in $\mathrm{R}^{87}$.

$y=\beta_{0}+f(t)+\epsilon$

In equation (1), $y$ is the response, $t$ is time, $\beta_{0}$ is the intercept, $\epsilon$ is the error term, and $f(t)$ is a linear combination of basis functions. Basis functions are described by equation (2).

$f(t)=\sum_{j=1}^{k} b_{j}(t) \beta_{j}$

In equation (2), $\beta_{j}$ is the weight associated with the $j$ th basis function. Here, each function was estimated as a weighted sum of two cubic basis functions (Supplementary Fig. 7, models are further described in Supplementary Table 2). We also determined linear regression slopes in true color and DOC for all six study lakes using ordinary least-squares fitting (Supplementary Table 1 and Supplementary Fig. 1).

\section{Principal components analysis}

We summarized variation in the FFF-ICP-MS data using principal components analysis, via the prcomp() function in $\mathrm{R}^{88}$ (the input matrix included a row for each lake sample and a column for each instantaneous concentration of $\mathrm{Al}, \mathrm{Cu}, \mathrm{Fe}, \mathrm{Mn}$, and $\mathrm{U}$ ). To limit the influence of outliers (e.g., high concentrations of colloidal $\mathrm{Mn}$ and $\mathrm{Fe}$ in the July sample of Powers Pond), we applied a natural-log transformation to the data and mean-centered all variables before computing the principal components. The transformed data were not multivariate normal according to a Shapiro-Wilk test ${ }^{89}$, and no values were imputed or deleted.
We also summarized the variation in DOC and color over time in the study lakes via principal components analysis. Both variables were meancentered and scaled to unit variance, but no outliers were removed, and no values were imputed. The input matrix was not bivariate normal according to a Shapiro-Wilk test ${ }^{90}$.

\section{DATA AVAILABILITY}

The FFF data described here are available at https://doi.org/10.5281/zenodo.4562867. These data are also available from the corresponding author upon request.

Received: 7 October 2020; Accepted: 8 March 2021; Published online: 09 April 2021

\section{REFERENCES}

1. Monteith, D. T. et al. Dissolved organic carbon trends resulting from changes in atmospheric deposition chemistry. Nature 450, 537-540 (2007).

2. Kritzberg, E. S. Centennial-long trends of lake browning show major effect of afforestation: Centennial-long trends of lake browning. Limnol. Oceanogr. Lett. 2, 105-112 (2017).

3. Meyer-Jacob, C. et al. The browning and re-browning of lakes: Divergent lakewater organic carbon trends linked to acid deposition and climate change. Sci. Rep. 9, 16676 (2019).

4. Weyhenmeyer, G. A. \& Karlsson, J. Nonlinear response of dissolved organic carbon concentrations in boreal lakes to increasing temperatures. Limnol. Oceanogr. 54, 2513-2519 (2009).

5. Wit, H. Ade et al. Current Browning of Surface Waters Will Be Further Promoted by Wetter Climate. Environ. Sci. Technol. Lett. 3, 430-435 (2016).

6. Meyer-Jacob, C., Tolu, J., Bigler, C., Yang, H. \& Bindler, R. Early land use and centennial scale changes in lake-water organic carbon prior to contemporary monitoring. Proc. Natl Acad. Sci. USA 112, 6579-6584 (2015).

7. Finstad, A. G. et al. From greening to browning: Catchment vegetation development and reduced S-deposition promote organic carbon load on decadal time scales in Nordic lakes. Sci. Rep. 6, 31944 (2016).

8. Evans, C. D., Chapman, P. J., Clark, J. M., Monteith, D. T. \& Cresser, M. S. Alternative explanations for rising dissolved organic carbon export from organic soils. Glob. Change Biol. 12, 2044-2053 (2006).

9. Björnerås, C. et al. Widespread Increases in iron concentration in European and North American freshwaters: increasing iron concentrations. Glob. Biogeochem. Cycles 31, 1488-1500 (2017).

10. Kritzberg, E. S. \& Ekström, S. M. Increasing iron concentrations in surface waters a factor behind brownification? Biogeosciences 9, 1465-1478 (2012).

11. Lawrence, G. B., Simonin, H. A., Baldigo, B. P., Roy, K. M. \& Capone, S. B. Changes in the chemistry of acidified Adirondack streams from the early 1980 s to 2008. Environ. Pollut. 159, 2750-2758 (2011).

12. Rotteveel, L. \& Sterling, S. M. Five aluminum seasonality regimes identified in chronically acidified rivers of Nova Scotia. Environ. Sci. Technol. https://doi.org/ 10.1021/acs.est.9b04872 (2019).

13. Visser, S. A. Seasonal changes in the concentration and colour of humic substances in some aquatic environments. Freshw. Biol. 14, 79-87 (1984).

14. Mierle, G. \& Ingram, R. The role of humic substances in the mobilization of mercury from watersheds. Water Air Soil Pollut. 56, 349-357 (1991).

15. Kent, F. C., Montreuil, K. R., Stoddart, A. K., Reed, V. A. \& Gagnon, G. A. Combined use of resin fractionation and high performance size exclusion chromatography for characterization of natural organic matter. J. Environ. Sci. Health, Part A 49, 1615-1622 (2014).

16. Tipping, E. \& Hurley, M. A. A unifying model of cation binding by humic substances. Geochim. Cosmochim. Acta 56, 3627-3641 (1992). 
17. Tipping, E., Backes, C. A. \& Hurley, M. A. The complexation of protons, aluminium and calcium by aquatic humic substances: a model incorporating binding-site heterogeneity and macroionic effects. Water Res. 22, 597-611 (1988).

18. Catrouillet, $\mathrm{C}$. et al. Geochemical modeling of Fe(II) binding to humic and fulvic acids. Chem. Geol. 372, 109-118 (2014).

19. Gu, B., Schmitt, J., Chen, Z., Liang, L. \& McCarthy, J. F. Adsorption and desorption of different organic matter fractions on iron oxide. Geochim. Cosmochim. Acta 59, 219-229 (1995)

20. Singer, P. C. Humic substances as precursors for potentially harmful disinfection by-products. Water Sci. Technol. 40, 25-30 (1999).

21. Reckhow, D. A., Singer, P. C. \& Malcolm, R. L. Chlorination of humic materials: byproduct formation and chemical interpretations. Environ. Sci. Technol. 24, 1655-1664 (1990).

22. Chen, Y. et al. Assessment of the chlorine demand and disinfection byproduct formation potential of surface waters via satellite remote sensing. Water Res. 165, 115001 (2019).

23. Anderson, L. E., Krkošek, W. H., Stoddart, A. K., Trueman, B. F. \& Gagnon, G. A. Lake recovery through reduced sulfate deposition: a new paradigm for drinking water treatment. Environ. Sci. Technol. 51, 1414-1422 (2017).

24. Gora, S. L. et al. Source water characteristics and building-specific factors influence corrosion and point of use water quality in a decentralized arctic drinking water system. Environ. Sci. Technol. 54, 2192-2201 (2020).

25. Gora, S. L. et al. Microbiological water quality in a decentralized Arctic drinking water system. Environ. Sci. Water Res. Technol. 6, 1855-1868 (2020).

26. Daley, K., Castleden, H., Jamieson, R., Furgal, C. \& Ell, L. Water systems, sanitation, and public health risks in remote communities: Inuit resident perspectives from the Canadian Arctic. Soc. Sci. Med. 135, 124-132 (2015).

27. Daley, K. et al. Chemical and microbial characteristics of municipal drinking water supply systems in the Canadian Arctic. Environ. Sci. Pollut. Res. 25, 32926-32937 (2018).

28. Lane, K., Trueman, B. F., Locsin, J. \& Gagnon, G. A. Inorganic contaminants in Canadian First Nation community water systems. J. Water Health 18, 728-740 (2020).

29. IUPAC Compendium of Chemical Terminology: Gold Book. (IUPAC, 2009). https:// doi.org/10.1351/goldbook.

30. Bolea, E. et al. Multielement characterization of metal-humic substances complexation by size exclusion chromatography, asymmetrical flow field-flow fractionation, ultrafiltration and inductively coupled plasma-mass spectrometry detection: a comparative approach. J. Chromatogr. A 1129, 236-246 (2006).

31. Neubauer, E., Kammer, Fvd \& Hofmann, T. Using FLOWFFF and HPSEC to determine trace metal-colloid associations in wetland runoff. Water Res. 47, 2757-2769 (2013).

32. Siripinyanond, A., Worapanyanond, S. \& Shiowatana, J. Field-flow fractionation -inductively coupled plasma mass spectrometry: an alternative approach to investigate metal-humic substances interaction. Environ. Sci. Technol. 39, 3295-3301 (2005).

33. Dubascoux, S. et al. Field-flow fractionation and inductively coupled plasma mass spectrometer coupling: history, development and applications. J. Anal. Spectrom. 25, 613-623 (2010)

34. Baalousha, M., Stolpe, B. \& Lead, J. R. Flow field-flow fractionation for the analysis and characterization of natural colloids and manufactured nanoparticles in environmental systems: a critical review. J. Chromatogr. A 1218, 4078-4103 (2011).

35. Lyvén, B., Hassellöv, M., Turner, D. R., Haraldsson, C. \& Andersson, K. Competition between iron- and carbon-based colloidal carriers for trace metals in a freshwater assessed using flow field-flow fractionation coupled to ICPMS. Geochim. Cosmochim. Acta 67, 3791-3802 (2003).

36. Stolpe, B., Guo, L., Shiller, A. M. \& Hassellöv, M. Size and composition of colloidal organic matter and trace elements in the Mississippi River, Pearl River and the northern Gulf of Mexico, as characterized by flow field-flow fractionation. Mar. Chem. 118, 119-128 (2010).

37. Clair, T. A., Dennis, I. F. \& Vet, R. Water chemistry and dissolved organic carbon trends in lakes from Canada's Atlantic Provinces: No recovery from acidification measured after 25 years of lake monitoring. Can. J. Fish. Aquat. Sci. 68, 663-674 (2011).

38. Redden, D. J., Trueman, B. F., Dunnington, D. W., Anderson, L. E. \& Gagnon, G. Chemical recovery and browning of Nova Scotia surface waters in response to declining acid deposition. Environmental Science: Processes \& Impacts. https://doi. org/10.1039/D0EM00425A (2021).

39. Tedetti, M., Cuet, P., Guigue, C. \& Goutx, M. Characterization of dissolved organic matter in a coral reef ecosystem subjected to anthropogenic pressures (La Réunion Island, Indian Ocean) using multi-dimensional fluorescence spectroscopy. Sci. Total Environ. 409, 2198-2210 (2011).

40. Huguet, A. et al. Properties of fluorescent dissolved organic matter in the Gironde Estuary. Org. Geochem. 40, 706-719 (2009).
41. Weishaar, J. L. et al. Evaluation of specific ultraviolet absorbance as an indicator of the chemical composition and reactivity of dissolved organic carbon. Environ. Sci. Technol. 37, 4702-4708 (2003).

42. Clement, P. M., Keizer, P. D., Gordon, D. C., Clair, T. A. \& Hall, G. E. M. Synoptic water quality survey of selected Halifax Regional Municipality lakes on 28-29 March 2000. http://science-catalogue.canada.ca/record=b4078272 S6 (2007).

43. Clement, P. M. \& Gordon, D. C. Synoptic water quality survey of selected Halifaxarea lakes. http://science-catalogue.canada.ca/record=b4078272 S6 (2019).

44. Westerhoff, P. et al. Low risk posed by engineered and incidental nanoparticles in drinking water. Nat. Nanotechnol. 13, 661-669 (2018).

45. Cuss, C. W., Grant-Weaver, I. \& Shotyk, W. AF4-ICPMS with the 300 da membrane to resolve metal-bearing 'colloids'<1 kDa: Optimization, fractogram deconvolution, and advanced quality control. Anal. Chem. 89, 8027-8035 (2017).

46. Trueman, B. F., Anaviapik-Soucie, T., L'Hérault, V. \& Gagnon, G. A. Characterizing colloidal metals in drinking water by field flow fractionation. Environ. Sci. Water Res. Technol. https://doi.org/10.1039/c9ew00560a (2019).

47. Gallego-Urrea, J. A., Tuoriniemi, J., Pallander, T. \& Hassellöv, M. Measurements of nanoparticle number concentrations and size distributions in contrasting aquatic environments using nanoparticle tracking analysis. Environ. Chem. 7, 67 (2010).

48. Thurman, E. M., Wershaw, R. L., Malcolm, R. L. \& Pinckney, D. J. Molecular size of aquatic humic substances. Org. Geochem. 4, 27-35 (1982).

49. Rosario-Ortiz, F. L., Snyder, S. A. \& Suffet, I. H. Characterization of dissolved organic matter in drinking water sources impacted by multiple tributaries. Water Res. 41, 4115-4128 (2007).

50. Masini, J. C. et al. Comparison of methodologies for determination of carboxylic and phenolic groups in humic acids. Anal. Chim. Acta 364, 223-233 (1998).

51. Bailey, S. W., Driscoll, C. T. \& Hornbeck, J. W. Acid-base chemistry and aluminum transport in an acidic watershed and pond in New Hampshire. Biogeochemistry 28, 69-91 (1995)

52. Driscoll, C. T. Aluminum in acidic surface waters: chemistry, transport, and effects Environ. Health Perspect. 63, 93-104 (1985).

53. Driscoll, C. T., Baker, J. P., Bisogni, J. J. \& Schofield, C. L. Effect of aluminium speciation on fish in dilute acidified waters. Nature 284, 161-164 (1980).

54. Frommell, D. M., Feld, C. M., Snoeyink, V. L., Melcher, B. \& Feizoulof, C. Aluminum residual control using orthophosphate. J. Am. Water Works Assn. 96, 99-109 (2004).

55. Zinder, B., Furrer, G. \& Stumm, W. The coordination chemistry of weathering: II. Dissolution of Fe(III) oxides. Geochim. Cosmochim. Acta 50, 1861-1869 (1986).

56. Cuss, C. W. et al. Measuring the distribution of trace elements amongst dissolved colloidal species as a fingerprint for the contribution of tributaries to large boreal rivers. Sci. Total Environ. 642, 1242-1251 (2018).

57. Dupré, B. et al. Major and trace elements associated with colloids in organic-rich river waters: Ultrafiltration of natural and spiked solutions. Chem. Geol. 160 63-80 (1999).

58. Baalousha, M. et al. Size-based speciation of natural colloidal particles by flow field flow fractionation, inductively coupled plasma-mass spectroscopy, and transmission electron microscopy/X-ray energy dispersive spectroscopy: colloids -trace element interaction. Environ. Sci. Technol. 40, 2156-2162 (2006)

59. Morrison, M. A. \& Benoit, G. Investigation of conventional membrane and tangential flow ultrafiltration artifacts and their application to the characterization of freshwater colloids. Environ. Sci. Technol. 38, 6817-6823 (2004).

60. Tipping, E., Rothwell, J. J., Shotbolt, L. \& Lawlor, A. J. Dynamic modelling of atmospherically-deposited $\mathrm{Ni}, \mathrm{Cu}, \mathrm{Zn}, \mathrm{Cd}$ and $\mathrm{Pb}$ in Pennine catchments (northern England). Environ. Pollut. 158, 1521-1529 (2010)

61. Chiswell, B. The speciation of manganese in freshwaters. Talanta 33, 669-677 (1986)

62. Ekström, S. M., Sandahl, M., Nilsson, P. A., Kleja, D. B. \& Kritzberg, E. S. Reactivity of dissolved organic matter in response to acid deposition. Aquat. Sci. 78, 463-475 (2016).

63. SanClements, M. D., Oelsner, G. P., McKnight, D. M., Stoddard, J. L. \& Nelson, S. J. New insights into the source of decadal increases of dissolved organic matter in acid-sensitive Lakes of the Northeastern United States. Environ. Sci. Technol. 46 3212-3219 (2012).

64. Baalousha, M. Aggregation and disaggregation of iron oxide nanoparticles: Influence of particle concentration, $\mathrm{pH}$ and natural organic matter. Sci. Total Environ. 407, 2093-2101 (2009)

65. Davison, W. Iron and manganese in lakes. Earth Sci. Rev. 34, 119-163 (1993).

66. Edzwald, J. K. \& Tobiason, J. E. Enhanced coagulation: US requirements and a broader view. Water Sci. Technol. 40, 63-70 (1999).

67. Keeley, J., Jarvis, P., Smith, A. D. \& Judd, S. J. Coagulant recovery and reuse for drinking water treatment. Water Res. 88, 502-509 (2016).

68. Kritzberg, E. S. et al. Browning of freshwaters: Consequences to ecosystem services, underlying drivers, and potential mitigation measures. Ambio 49, 375-390 (2020).

69. Trueman, B. F. et al. Manganese increases lead release to drinking water. Environ. Sci. Technol. 53, 4803-4812 (2019). 
70. Trueman, B. F. \& Gagnon, G. A. Understanding the role of particulate iron in lead release to drinking water. Environ. Sci. Technol. 50, 9053-9060 (2016).

71. Trueman, B. F. et al. Galvanic corrosion of lead by iron (Oxyhydr)oxides: potential impacts on drinking water quality. Environ. Sci. Technol. 51, 6812-6820 (2017).

72. Trueman, B. F. \& Gagnon, G. A. A new analytical approach to understanding nanoscale lead-iron interactions in drinking water distribution systems. J. Hazard. Mater. 311, 151-157 (2016).

73. Purchase, J. M., Rouillier, R., Pieper, K. J. \& Edwards, M. Understanding failure modes of NSF/ANSI 53 lead-certified point-of-use pitcher and faucet filters. Environ. Sci. Technol. Lett. https://doi.org/10.1021/acs.estlett.0c00709 (2020).

74. Lytle, D. A. et al. Lead particle size fractionation and identification in Newark, New Jersey's drinking water. Environ. Sci. Technol. 54, 13672-13679 (2020).

75. Health Canada. Guidelines for Canadian drinking water quality: Guideline technical document: Manganese. (2019).

76. Health Canada. Guideline technical document for consultation: Aluminum in drinking water. (2019).

77. Zamyadi, A. et al. Toxic cyanobacterial breakthrough and accumulation in a drinking water plant: a monitoring and treatment challenge. Water Res. 46, 1511-1523 (2012).

78. Urrutia-Cordero, P., Ekvall, M. K. \& Hansson, L.-A. Local food web management increases resilience and buffers against global change effects on freshwaters. Sci. Rep. 6, 29542 (2016).

79. Taranu, Z. E., Gregory-Eaves, I., Steele, R. J., Beaulieu, M. \& Legendre, P. Predicting microcystin concentrations in lakes and reservoirs at a continental scale: a new framework for modelling an important health risk factor. Glob. Ecol. Biogeogr. 26, 625-637 (2017)

80. Tarr, C. \& White, C. E. Acid Rock Drainage in the Chain Lakes Watershe, Halifax Regional Municipality, Nova Scotia. in Geoscience and Mines Branch Report ME 2016-001: Report of Activities 2015 109-119 (Nova Scotia Department of Natural Resources, 2016).

81. Mudalige, T. K., Qu, H., Sánchez-Pomales, G., Sisco, P. N. \& Linder, S. W. Simple functionalization strategies for enhancing nanoparticle separation and recovery with asymmetric flow field flow fractionation. Anal. Chem. 87, 1764-1772 (2015).

82. Hassellöv, M., Readman, J. W., Ranville, J. F. \& Tiede, K. Nanoparticle analysis and characterization methodologies in environmental risk assessment of engineered nanoparticles. Ecotoxicology 17, 344-361 (2008).

83. Aureli, F., D'Amato, M., Raggi, A. \& Cubadda, F. Quantitative characterization of silica nanoparticles by asymmetric flow field flow fractionation coupled with online multiangle light scattering and ICP-MS/MS detection. J. Anal. Spectrom. 30, 1266-1273 (2015)

84. American Public Health Association. 5310 total organic carbon (TOC) (2017). in Standard Methods For the Examination of Water and Wastewater. https://doi.org/ 10.2105/SMWW.2882.104 (2018).

85. American Public Health Association. 3125 metals by inductively coupled plasma -mass spectrometry (2017). in Standard methods for the examination of water and wastewater. https://doi.org/10.2105/SMWW.2882.048 (2018).

86. Brophy, M. J., Trueman, B. F., Park, Y., Betts, R. A. \& Gagnon, G. A. Fluorescence spectra predict microcystin-LR and disinfection byproduct formation potential in lake water. Environ. Sci. Technol. 53, 586-594 (2019).

87. Wood, S. N. Generalized additive models: An introduction with r. (Chapman; Hall/ CRC, 2017).

88. R Core Team. R: A language and environment for statistical computing. (R Foundation for Statistical Computing, 2019).

89. Jarek, S. Mvnormtest: Normality test for multivariate variables. (2012).
90. Gonzalez-Estrada, E. \& Villasenor-Alva, J. A. MvShapiroTest: Generalized shapirowilk test for multivariate normality. (2013).

\section{ACKNOWLEDGEMENTS}

This work was funded by the Natural Sciences and Engineering Research Council of Canada (NSERC) postgraduate scholarship program (D.W. Dunnington, L.E. Anderson) and the NSERC Halifax Water Industrial Research Chair program (G.A. Gagnon, NSERC Grant No. IRCPJ: 349838-16). We acknowledge the technical support of Mikaela Zwicker, Heather McGuire, Talija Menegotto, and Heather Daurie.

\section{AUTHOR CONTRIBUTIONS}

L.A., B.T., and D.D. are co-first authors. L.A. performed the bulk water analysis and contributed to data analysis and writing; B.T. performed the FFF separation and contributed to data analysis and writing; D.D. collected the samples and contributed to data analysis and writing; G.G. acquired funding, supervised the project, and edited the manuscript.

\section{COMPETING INTERESTS}

The authors declare no competing interests.

\section{ADDITIONAL INFORMATION}

Supplementary information The online version contains supplementary material available at https://doi.org/10.1038/s41545-021-00115-4

Correspondence and requests for materials should be addressed to B.F.T.

Reprints and permission information is available at http://www.nature.com/ reprints

Publisher's note Springer Nature remains neutral with regard to jurisdictional claims in published maps and institutional affiliations.

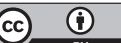

Open Access This article is licensed under a Creative Commons Attribution 4.0 International License, which permits use, sharing, adaptation, distribution and reproduction in any medium or format, as long as you give appropriate credit to the original author(s) and the source, provide a link to the Creative Commons license, and indicate if changes were made. The images or other third party material in this article are included in the article's Creative Commons license, unless indicated otherwise in a credit line to the material. If material is not included in the article's Creative Commons license and your intended use is not permitted by statutory regulation or exceeds the permitted use, you will need to obtain permission directly from the copyright holder. To view a copy of this license, visit http://creativecommons. org/licenses/by/4.0/.

(c) The Author(s) 2021 